Journal of English Language Teaching

\title{
English Teachers' Methods in Teaching Reading Comprehension of Procedure Text
}

\author{
Akidatul Yusmalinda, Puji Astuti ${ }^{凶}$
}

English Department, Faculty of Languages and Arts, Universitas Negeri Semarang, Indonesia

\begin{tabular}{l} 
Article Info \\
\hline Article History: \\
Received in 12 May \\
2020 \\
Approved in 12 July \\
2020 \\
Published in 30 July \\
22020 \\
\hline Keywords: \\
English Teacher; \\
Teachers' Methods; \\
Teaching Reading; \\
Reading \\
Comprehension; \\
Procedure \\
\hline
\end{tabular}

\begin{abstract}
This study focuses on English teachers' methods in teaching reading comprehension of procedure text. The main purpose of this study is to describe the methods used by English teachers and reveal the strengths and weaknesses of those methods used for teaching reading comprehension of procedure texts. The research was a qualitative case study. The participants of this research were two English teachers at one of junior high schools in Semarang in the academic year of 2019/2020. In collecting data, several data collection instruments were used, including: interview, observation guideline and document analysis checklist. The findings showed that English teachers planned the teaching materials and strategies in advance. They also used various methods in teaching reading of procedure text. Both teachers almost used the same methods which were audio-visual method, scaffolding, grammartranslation method, and project-based learning. The difference was in the step of the strategy implementation. In addition, the findings showed that the most appropriate method in teaching reading comprehension was grammar-translation method since it helped students comprehend the procedure text. There were several students who still had a hard time following the lessons. Teachers are supposed to make sure that all students have understood the whole text or not and they should observe the students' situation and needs so that the teaching and learning is contextual.
\end{abstract}

(C) 2019 Universitas Negeri Semarang

\footnotetext{
Correspondent Address:

B3 Building FBS Unnes

Sekaran, Gunungpati, Semarang, 50229

E-mail: yusmalinday@gmail.com
} 


\section{INTRODUCTION}

It is a fact that English has been chosen as an international language because of widespread use among all countries in the world. Therefore, it is obviously significant for all people to learn English in every level by considering the importance of daily life in all skills. Therefore, people have to master all the required skills in English such as listening, reading, speaking, and writing. These four skills cannot be separated, they are linked to each other and related to receptive skills and productive skills. While listening and reading are receptive skills, writing and speaking are productive skills (Harmer, 2001).

Due to the fact that reading is a receptive skill, it means reading is one of the ways to get the knowledge in English, because when we read a text we can obviously get the knowledge what exactly the text tells to us, in addition, we can get a lot of vocabularies that will help us in speaking and writing. Hence, reading skills is very important especially for students to collect as many as possible the vocabulary from the text they have read. By reading, students can use their time in a good way to get information, knowledge, as well as enrich their vocabulary, and improve their ability in English.

According to Dean (2013), reading is more than seeing words clearly, more than pronouncing printed words correctly and more than recognizing the meaning of isolated words. Reading requires you to think and feel. Reading is not just looking and pronouncing words in the text but comprehending all the components of a text. In short, the goal of all reading is the comprehension of meaning that is conveyed in the written text.

Students in junior high school are supposed to learn several genres of text. According to Indonesia Curriculum Education 2013, there are several texts that must be studied such as descriptive text, narrative text, procedure text, and so on. Each of them has different generic structure, aim, and also language features. Hence, it would make students difficult either to identify or differentiate the text. Since we know that they must understand the whole text; what the writer tries to inform and tell the readers. Moreover, students must get the knowledge and information of the text, they have to be able to think critically, so whenever they are asked to answer some questions based on the text they have read, they can answer it correctly.

In addition, as we know, nowadays the National Examination (UN) is not a key to determine whether the students pass or fail in Junior High School. Yet, the function of the UN has changed, it becomes the standard of education quality of Indonesia. Besides, for students, the result of their National Examination will be a consideration of entering the next level of education which is senior high school and the next after is university. If they do not succeed in answering the whole question means they might have difficulty in the future for students who want to apply for school in their out zone since their final marks will be a consideration for its school. According to the POS, all the questions of UN are from the material from seventh to ninth of Junior High School which means the students need to brush up on their memory of all materials. Due to the importance of English and National Examination, students were worried about having a bad score in National Examination. Therefore, students had to work hard to pass the National Examination.

Nevertheless, those things are not easy because one text contains of a lot of vocabulary, grammatical structure and also its story which has differences with other texts. The students need an extraordinary effort to comprehend all the text, so they can master the whole text and answer the questions related to the text. That understanding text is called by reading comprehension.

Hence, the teacher should help the students with all their difficulties. The teacher must consider what the best way to teach reading. In teaching reading, a teacher may use many different methods. According to Brown (2002) method is a generalized set of specifications in the classroom for achieving linguistic objectives. Methods main concern is to teachers and learners' role and behavior. Besides, the concern of method is to linguistic and subject matter objectives, sequencing and materials. This is the key of success of the reader. A teacher needs to select which one that must be implemented in teaching certain text so that students can easily get the knowledge of that text. Preparing students for what they are going to read can make comprehension much easier.

Teacher as a mediator in teaching at school is supposed to help students getting the best education in their life. If the students faced a difficulty in studying, it is teacher's obligation to help them. Based on the reason that I have been mentioned, students need teachers' help in mastering all skills of English, especially in reading comprehension. However, teaching reading is not as easy as we think, because it is not only asking the students to read the whole words in the text but 
encouraging them to understand the text even conduct a critical thinking. Hence, Teacher should consider what method or strategy that could make a reading text easier.

On the other hand, most of the previous researchers conducted their studies in order to find out what the difficulty that were facing the students and teachers in reading (Masadeh, 2015) and what teachers' perception on reading method (Ness, 2016). As well as some of them found that reading strategies will help students in improving their reading comprehension. In addition, in teaching reading teachers have used an interactive method and strategy in order to make the reading text easier for students, whereas other teachers still used a traditional method and questions in textbook as a media for teaching reading comprehension.

There were many previous studies that discussed about teachers strategies and methods in teaching reading comprehension such as done by Soleimani and Hajghani (2013), Ferdila (2014), Souhila (2014), Almasri and Alshumaimeri (2016), and Muslaini (2017). Soleimani and Hajghani (2013) found that reading strategy instruction can lead to the use of an extended range of reading strategies by the learners. Besides, the reading strategies are able to enhance students' reading performance. Ferdila (2014) found that teachers should find an appropriate technique to encourage students' interest instructions in various levels of Indonesian school dominantly adjust to intensive reading. Thus, this study was to investigate the benefits of using extensive reading in teaching reading and as well as students' attitudes toward it. The result showed that Hence, extensive reading can be used as one of the method or strategy to teach reading. It can be a resource or an option for the teacher when they want to teach a certain genre. Souhila (2014) found that students had some difficulties in approaching reading strategies task. It confirmed that reading is a challenging and complex skill because students showed that they have a great awareness about reading, but unfortunately they have lacked some of reading strategies. The result showed that there was a strong relationship between the students' knowledge (whether linguistic and background) and their success in applying strategies of reading about the text (whether general or specific).Almasri and Alshumaimeri (2016) found that the performance of the students in the control and the experimental group improved significantly in reading comprehension scores. However, the strongly significant differences occurring in the experimental group's post-test comprehension performance when compared to the pre-test indicate that using Web-Quest can improve students' reading comprehension performance. The authors suggest that the teacher's experience of the Web-Quest tool, and the challenges to its integration in the blended learning classroom, should be investigated further. Muslaini (2017) conducted a study with the objective were to find out how reading comprehension was taught at an Islamic boarding school in Pidie Jaya, the strategies that were used by the teachers for teaching reading comprehension, and the responses of the students towards the teaching-learning of reading comprehension. Based on the observations, both of the teachers used various strategies to teach reading comprehension. They were both very creative in handling their classes and they made the students actively involved in the teaching-learning for English reading comprehension.

From those studies that have been conducted, it was just a few studies examining about how the teachers teach reading comprehension in class. This is a gap in the literature. The previous researchers have not investigated yet what the strategies that are used by teachers in teaching reading comprehension. For instance, how the teachers find the appropriate method for teaching reading, how they conduct their lesson plan, whether they teach reading based on curriculum or not.

The notes above show that teachers play an important role in teaching their students in order to make them comprehend and master the reading skill. A good and appropriate method is really needed for students in comprehending the reading text, Medina (2012). As a teacher, they have to choose and select which best method that is good to be implemented in class and also the teaching method must be modified depending on the students' needs.

Based on these gaps, the study focused on conducting a research which aimed to find out what the strategies that are used by teachers in teaching reading comprehension. One main reason for conducting this research because there were just few studies discuss about that topic since we know that reading method is essential for teaching reading and also by conducting this topic we can know whether the teachers' strategies are appropriate or not for the students in learning reading comprehension especially in procedure text. 


\section{METHODS}

This section describes the research approach used, respondents involved in the study, if any, which should be kept confidential, instruments, procedures of collecting the data, and ways of analyzing the data. The blueprint of the instrument may be provided if necessary. Commonly used statistical formula should not be putin this section.

In the present study, it used qualitative approach as the research design. According to Creswell (2003), a qualitative approach is one in which the inquirer often makes knowledge claims based primarily on constructivist perspectives or advocacy/participatory perspectives or both. It also uses strategies of inquiry such as narratives, phenomenologies, ethnographies, grounded theory studies, or case studies. The researcher collects open-ended emerging data with the primary intent of developing themes from the data. In this present study, we used qualitative case study research since this study focused in answering "what" questions. This research used that method because it was also appropriate to the objectives of the research which focused on teachers' strategies in teaching reading comprehension. The results of the research emphasized in the form of words and it was presented in narrative.

The results of the research emphasized in the form of words and it was presented in narrative. The data taken from the interview answered the questions from the interviewer while the observation examined the correlation between the interviewee' answer and his/her action in class. In addition, the use of document analysis help the data more accurate and valid. The data was also recorded in a form of audio which later on would be examined and re-examined to minimize the mistakes in analyzing the data.

\section{Respondents}

The research participants of this study were two English teachers at one of junior high schools in Semarang in the academic year 2019/2020.

\section{Data collection methods procedures}

An instrument is a tool for measuring, observing, or documenting data. It includes interview, questionnaire, observation, and test (Saleh, 2012). To generate findings in a systematic way, it is needed to have some instruments in the research. The instruments that used to collect the data from the research participants were interview, observation and document analysis.

\section{Data collection procedures}

This research used in-field analysis Gibson and O'connor Model (2017) to analyze the data. Data analysis in qualitative research, conducted at the time of data collection took place, and after completion of data collection in a certain period. The process of analyzing data consists of five steps, there are organizing the data, finding and organizing ideas and concepts, identify patterns and connections within and between categories, and interpretation.

Therefore, in this study, we used methodological triangulation was applied in this study because there were three data techniques used which were interview, observation and document analysis. Interview and observation correlated to each other, which meant the two data supported each other in drawing the data to the conclusion. The document analysis made the study more accurate. We used the triangulation technique in order to get the most valid data as possible. Using triangulating data, it attempt to provide 'a confluence of evidence that breeds credibility' (Eisner, 1991). By examining information collected through different methods, the researchers could corroborate findings across data sets and thus reduced the impact of potential biases that can exist in a single study.

\section{FINDINGS AND DISCUSSION}

The main purpose of this research is giving the readers detail information about strategies used by English teachers in teaching reading comprehension especially in procedure text. Moreover, the strengths and weaknesses of each strategies will be explained as well.

After doing the research, I found that there are three strategies mostly used by English teachers in teaching procedure text. Those strategies are scaffolding and audio visual method, grammar translation method and project based learning. Besides, the findings are divided into two parts. 


\section{Three methods used by English teachers' in teaching reading comprehension of procedure text Scaffolding and Audio Visual Method}

In attaining the goal of comprehension, Mrs. Gea and Mrs. Nia had done a scaffolding method in advance. They had similar thought in gaining students' attention but they did it in a different way. Mrs. Gea created attracted-materials such as colorful photos and videos related to procedure text which often about food in order to be showed and seen by students on LCD screen. This method aimed to gain the students' attention and build a concept of the material that are going to be taught in class.

On the other hand, Mrs. Nia also did scaffolding in different way. She began the class by giving a text or asking the students to open the book and read a certain text about procedure text. The teacher would read the text first, sentence by sentence then the students would repeat. The objective of such activity was to make the students reading aloud the text so that they are accustomed to the vocabulary and the text. After read the text, she also played a video in order to make the students more understand about what the procedure text is since it will be difficult to comprehend the text by only reading it.

\section{Grammar-Translation Method}

Mrs. Gea and Mrs. Nia did the grammar-translation method after asking the students to read the text. She said that grammar-translation method is a must since the students learnt foreign language which absolutely was difficult to be mastered. At class, she asked what point they did not understand, and difficult words of the text. The teacher opened a question and answer section and discussion within the method which aimed to ask the students about the difficult words in such text. If they did not know the meaning, teacher explained the certain word by giving a movement such gestures to represent the meaning of the word. The students were enthusiastic in mentioning the words and got the idea of the content of the text. It help the students mastering the content of the text (see appendix 1).

Mrs. Gea and Mrs. Nia used grammar translation method in order to help students converting the words from English into Bahasa so that they can easily comprehend the content of procedure text. In translating the words teachers used some gestures to represent the meaning of the text to stimulate the students' mind in guessing the word. That such method was really effective for students in comprehending the text. So that they can easily answer the questions related to the text.

\section{Project-Based Learning}

According to teachers' interview, they both said that procedure text often related to how to make something. So, they wanted the students not only able to read and understand the text but also practice and implement the content of text in real life. So, both teachers used project based learning as final assignment to be done in the last meeting. Mrs. Gea divided their students into some groups and each group were asked to choose one of the recipes to be demonstrate in front of class. She recorded the performance as a reflection of the learning process.

Moreover, Mrs. Nia also did the same method as Mrs. Gea. She grouped the students in order to train their skill in performing the recipe in front of the class. Most of them demonstrated the menu or food the next meeting, and then Mrs. Nia assessed their performance.

\section{The strength and weaknesses of three methods used in teaching procedure text Scaffolding and audio-visual method}

From the data of interview and observation that I got, this method had some strengths and also weaknesses. First, when Mrs. Gea used scaffolding by showing pictures and videos all students were enthusiastic in watching the video, the pictures could attract students' attention. So, they were really enjoy the learning process through media such as power-point and video. On the other hand, when teacher asked the students some questions related to the video, not all students were active in answering those questions. Some of them understood the content of the text, but others just focused on images which showed up on screen. Besides, the position of the screen was not on the center of class, so the students who were sitting at the back corner of class could not see the power point clearly. It also had impact on their reading comprehension. When they read the text on the screen, they might miss some words, so their understanding of the content were less than others. 
Besides, when Mrs. Nia used scaffolding by giving all the students printed text, they all seemed seriously read the text since the reason Mrs. Nia gave the strategy was because she wanted the students got used to in reading procedure text. Reading the text made the students understood in pronouncing new vocabularies that came up in text, yet they might not pay attention to the content of the text. So when she asked some questions related to the text, students must read again the text in order to build the comprehension of the text.

\section{Grammar-translation method}

This method is really helpful since first language of the students is Bahasa, they needed a certain strategy to make them understand the whole text. Mrs. Gea and Mrs. Nia used grammar translation method in order to help students converting the words from English into Bahasa so that they can easily comprehend the content of procedure text. From observation, I saw that students can understand the whole text easily since they succeed in finding the meaning of difficult words that came up in the text. Besides, in translating the words teachers used some gestures to represent the meaning of the text to stimulate the students' mind in guessing the word. That such strategy was really effective for students in comprehending the text. So that they can easily answer the questions related to the text.

In addition, from the interview, I have asked both teachers about the weakness of using grammar-translation method in teaching procedure text. The result showed that grammar-translation method is the only one method which has not any weaknesses from teachers' point of view. This strategy was appropriate in teaching reading comprehension about procedure text.

\section{Project-based learning}

The third method that used by English teacher in teaching reading procedure text was project-based learning. This method was very effective in training students skill in speaking since they were supposed to perform in front of class. Nevertheless, the aim of using such strategy was to assess students understanding of procedure text. This method was effective because it would stimulate students' ability in speaking so that all students have the same opportunity to demonstrate the recipe of certain food.

Yet, the speaking skill can be achieved if the students master the whole text. If the students have mastered the whole text, they can perform properly. This method was effective in stimulating students in order to understand the text, so that they can train their speaking skill in front of class. Yet, this method used so much time because one group may perform more than 15 minutes and the effect was not all students can perform properly.

\section{Discussion}

In teaching and learning process teachers had designed such the lesson plan so that they know what should do in class. They set such activities and decided what methods which are suitable and appropriate to be implemented. They had written step by step in teaching procedure text, start from the beginning of class by preparing students to pray, motivating, giving a material and assessing the students' comprehension and skill. In class, they had done such activities they planned in advance, but sometimes they did improvisation due to the class and students' situation.

Nevertheless, each teacher had difference in beginning the materials in class. Mrs. Gea showed the video and pictures to introduce the materials, so that students could guess and grab the idea of the materials. Besides, Mrs. Nia began the class by giving a text or asking the students to open the book and read a certain text about procedure text. The teacher would read the text first, sentence by sentence then the students would repeat. The objective of such activity was to make the students reading aloud the text so that they were accustomed to the vocabulary and the text. Afterward, what she had done in continuing the teaching and learning process almost the same as with Mrs. Gea. Both teachers discussed the materials such as asking the unfamiliar words in text which made students difficult in comprehending the text then teachers translated those words together with the students. Teachers used to call the process as grammar-translation method.

Krashen (1987) the aim of language learning in this method is described as to help students attain the ability of reading the literature of the source language by studying its structures and 
lexicon, with a special weight on grammar rules, vocabulary memorization and written translations into and out of the target language, with a strong focus on the form and meaning. Students learn new vocabulary and grammatical rules through their own native language. It is also widely used in explanation about new concept. Meaning of the target language items is made clear via translation into students' native language. As my observation, students are involved in translating the reading text from their book into Bahasa after reading aloud by lines or sentences. As I have seen in the experience, individual students do the translation orally, yet the teacher can also ask students to write down their translation in their notebooks, as well.

Teachers also did not forget to explain the materials more detail and deeper as they explained what the text was and video told about, the function, generic structure and also the common words which often appear in procedure text. While explaining, teachers also often gave several oral questions, and students answered it orally. At the end of the discussion, teachers gave written question to the students so that the teacher would know how the process of understanding the material especially in procedure text in each students. Yet, Mrs. Nia added some task from the questions of national examination. She wanted her students familiar with each kind of questions, because sometimes the question about procedure text can be unfamiliar for students due to the use of words. For example, the question would be about the function of the text, yet the writer used the synonym of the word "objective" like goal or aim. By giving the different type of questions, students are supposed to train in understanding what the question wants to ask.

After giving a lot of explanation and task related to procedure text, teacher wanted the students to use their comprehension in real life. This will be happened by asking the students to perform. Teachers divided the students into some group and ask them to find a recipe or any kind of procedure text that related to their life, and after that they asked them to perform in front of class. Teachers will assess their performance and also knowledge by measuring their pronunciation, intonation, teamwork and their performance whether they gave the explanation of their project by reading the text or they have mastered the text so they can do it without reading any text. This process is called project based learning.

According to Jalinus, Nabawi and Mardin (2017) in project-based learning, students are the center of learning who are learning actively to improve their competences. Teachers act more as a guide since it is student-centered. Project based learning focuses on a real-world problem in this case, the students' work related to their life such as an easy recipe that can be made in their real life. The significant improvement that occurred in ability doing project work could be seen from skilled student in preparing the materials, the materials and ingredients in accordance with procedure, managing of work, managing of time, cooperation with team work more solid and show better work attitude. The most important thing is the ability of comprehending the text.

Teacher chose and prepared such strategies and methods because they thought those were appropriate in teaching reading comprehension in particularly procedure text. The use of scaffolding aimed to build a concept of procedure text, stimulate students' mind, and also attract students' attention. When students had focus on the teacher and materials, teachers gave warming-up material by discussing about what the video was, what the text was and guessing the content. It can motivate the students to learn new materials. While learning new materials students surely got some obstacle in learning. Thus the teacher helped them by asking difficult words, translating so that students felt helped and easy to understand the materials. Discussing in question and answer session was a way to know whether the students have understood the material or not, if the students can answer the whole questions and know the whole text or what the content of the text, teacher can move forward to the next step. The goal of the use project based learning as final project in procedure text was to make each individual student not only able to read aloud and translate the words from English into Bahasa, but also understand and comprehend the content of the text. The result was they could implement their understanding into skill by performing a certain text in front of class. They thought that by demonstrating a certain procedure text into performance means they were able to understanding and comprehension the text, especially when they performed without text. It concluded that they comprehend the text well. By doing so, teacher could assess students' comprehension and also skill through performance, besides giving a certain text with some questions to be answered in order to know the students' comprehension in reading procedure text. Giving a text and some questions relate to text can be a training for students to achieve reading comprehension as the more they read, the more they know and feel familiar about the words which often appear in procedure text. 
Nevertheless, Mrs. Gea and Mrs. Nia did not mention the name of each strategy either in class or in lesson plan they conducted. They both only gave materials, instruction as they set in advanced. They just simply wrote discovery learning as approach and learning method without writing detail each strategy that will be used in class. They should have written all methods and activities in lesson plan in order to measure whether what they have done in class as same as with the lesson plan or not. In addition, mentioning the strategy in class is also important since the students will know what they are going to do in that learning process. It can be done by changing the name of strategy with any easy term which make students understand the aim of learning activities in class.

Observing the students' respond, actually not all students were active in learning process even teachers had set and prepared such materials and methods using medium, some students seemed not focus so that when teacher asked, they could not answered it. It also happened when teacher gave an exercise and asked them to write the answer, they were wrong in finding the correct answer. From five questions, most of students could not answer one question that was about implicit question, for example the question was about "how long does it take to cook rice?", most students answered the written-minutes, but actually the answer was implicit. On the other hand, when it came to question and answer section orally, they seemed enthusiastic and scrambling in answering the meaning of words.

From the result of study showed that project based learning has been implemented in teaching procedure text, yet it just focused on how the implementation of such strategy at class and the process of students' activity. Students were encouraged to collaborate in teamwork duty, stimulated to master their portion of duty in group. It can be concluded that project based learning has been used to teach procedure text.

The result of this observation related to the study conducted by Tan (2016) he said that grammar translation method and task based language teaching were two effective teaching methods in reading and they did improve Chinese college students' reading comprehension over a certain period of time.

Based on two previous studies, those two methods were appropriate in teaching. That is the reason why I choose to examine the methods used by English teacher in teaching reading comprehension in particular procedure text because there are some methods and strategies which proven effective in teaching reading.

Krashen (1982) the second way to develop competence in a second language is by language learning. The term "learning" henceforth to refer to conscious knowledge of a second language, knowing the rules, being aware of them, and being able to talk about them. In non-technical terms, learning is "knowing about" a language, known to most people as "grammar", or "rules". Some synonyms include formal knowledge of a language, or explicit learning. Those points mean that reading comprehension is one of the input in acquiring English especially for Indonesian students as the second language.

Those point of Krashen meant that reading comprehension help students in acquiring English as their second language. By knowing new vocabulary that came up in text as many as possible make them collect those word in memory so the library of words will increase day by day. In the end, they could master English well.

In line with the result of the study I did at one of junior high schools in Semarang, teachers had prepared and chose the best methods in teaching reading about procedure text. Hence, they did some activities in class using three best method that they thought can build students' reading comprehension. What I saw in my observation, teachers did not only pay attention on how students could understand the text well, but also how the students can use and apply the procedure text in real life which can be achieved if the students have really comprehend the content of the text. If students have understood what the text is going to tell, they can implement that meaning and aim of the text, they can show or perform it in front of their friend and others.

Thus all activities that had been done in class were connected one to another. The most important thing is students must achieve the reading comprehension of procedure text if they want to train other skills such as speaking and writing. The result of my observation showed that the teachers had drilled the students to read and understand the text using three methods I had mentioned. So, they get accustomed to reading procedure text and understanding the context of the text. At the end, they all have mastered the reading comprehension of procedure text, it also can be seen from their performance in class. 


\section{CONCLUSION}

The strategies used by English teachers can be concluded as, Mrs. Gea conducted the lesson plan in advance, then did audio visual method by showing video and pictures, and scaffolding by showing the text related to the video. After that she did grammar translation method, then giving question and answer session by discussion and also as individual work. The last she implemented the project based learning to know the students' comprehension into performance. On the other hand, Mrs. Nia conducted lesson plan in advance, then reading aloud the text, did scaffolding after that, showed video used audio visual method, then grammar translation method, thus giving question and answer session and the last she implemented the project based learning to know the students' comprehension into performance.

In short, those English teachers had used various strategies in teaching reading comprehension. They did not only use one method to teach all students. The three strategies that most used by English teachers were scaffolding and audio visual method, grammar-translation method and project based learning.

Moreover, the most appropriate method in teaching reading comprehension according to English teachers was grammar-translation method as it really helped students understanding the text easily. Second, project based learning, it stimulated the students to work in group and trained their speaking skill which obtained from the result of reading and comprehending the procedure text. The last but not least, scaffolding and audio-visual method since it really worked on attracting the students to focus on the materials and introduced them what kind of text they were going to learn.

The use of different methods is good in order to make students understand the materials due to the fact that students have difference ability, needs and background knowledge. By using miscellaneous strategies may help teacher in teaching process, because we never know which method that appropriate to such students. The result may be different from one students and others.

From that point a view means teachers had made and conducted the materials and strategies as good as possible yet the point of success and effectiveness of the use of a certain strategies can be achieved not only from the teachers' side but also from the students' side, since each students has difference background knowledge, needs, ability, the situation of students in class at that day can be influenced as well. So, that is difficult to know whether a particular method is effective or not. It has to be done in a long time to prove it.

Moreover, for further researcher could ask and interview students' whether what teachers did in class related to teaching reading comprehension in procedure text has made them understand the materials and text or not. Besides, post interview after doing an observation class is good to be done. This method can be used as reflection in teaching and learning process. So, for the next researcher can do this method to make the research more valid.

\section{ACKNOWLEDGMENT}

I would like to give my deepest gratitude to my advisor Puji Astuti, S.Pd., M.Pd., Ph.D. for her patience in giving me guidance and meaningful suggestions during the consultations for this final project. Moreover, the twenty six participants who belong to those abstracts. In addition, they were willing to become the participants of this final project.

\section{REFERENCES}

Almasri, Meshail M. \& Alshumaimeri, Yousif A. (2016). The effects of using web quests on reading comprehension performance of saudi efl students. Saudi Arabia: King Saud University.

Brown, H. D. 2002. Teaching by principles: An interactive approach to language pedagogy-second edition. New York: Addison Wesley Longman, Inc.

Creswell, John W. 2003. Research design: Qualitative, quantitative, and mixed method approaches -2nd ed. California: Sage Publication, Inc.

Dean, G. (2013). Teaching Reading in the Secondary Schools. Second edition. London: David Fulton.

Eisner, E. W. (1991). The enlightened eye: qualitative inquiry and the enhancement of educational practice. Toronto: Collier Macmillan Canada.

Ferdila, Raihani. (2014). The use of extensive reading in teaching reading. Journal of English and Education, 2(2), 68-80. Indonesia: Indonesia University of Education.

Gibson, Nancy \& O'Connor, Helene. (2017). A step by step guide to qualitative data analysis. $A$ journal of Aboriginal and Indigenous Community Health, 1 (1). 
Harmer, Jeremy. 2001. The practice of english language teaching. United Kingdom: Longman.

Jalinus, Nizwardi., Nabawi, Azis Rahmat., \& Mardin, Aznil. (2017). The seven steps of project based learning model to enhance productive competences of vocational students. Education and Humanities Research. Padang: Universitas Negeri Padang.

Krashen, S. D. (1982). Principles and practice in second language acquisition. University of Southern California.

Krashen, S. D. (1987). Principles and practice in second language acquisition. London. Prentice Hall International.

Masadeh, Thouqan Saleem Yakoub. (2015). Performance of saudi english language teachers in reading comprehension classes. SAGE Open, 1-10.

Medina, Sergio Lopera. (2012). The effects of strategy instruction in a efl reading comprehension. Colombia: Universidad de Antioquia.

Muslaini. (2017). Strategies for teaching reading comprehension. English Education Journal, 8(1), 6778. Banda Aceh: Syiah Kuala University.

Ness, M. K. (2016). Reading comprehension strategies in secondary content area classrooms: Teacher use of and attitudes towards reading comprehension instruction. Reading Horizons: $A$ Journal of Literacy and Language Arts, 49 (2).

Soleimani, Hassan \& Hajghani, Sajadeh. (2013). The effect of teaching reading comprehension strategies on iranian efl pre-university students' reading comprehension ability. International Research Journal of Applied and Basic Sciences, 5 (5), 594-600.

Souhila, Rouai. (2014). The use of reading strategies in improving reading comprehension. University Kasdi Merbah Ouargla. 